\title{
INTERIM SOLIDIFICATION OF SRP WASTE WITH SILICA, BENTONITE, OR PHOSPHORIC ACID
}

G. H. THOMPSON

TIS FILE

RECORD COPY

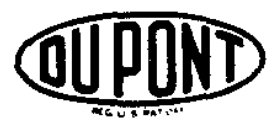

SAVANNAH RIVER LABORATORY AIKEN, SOUTH CAROLINA 29801

PHEPARED FOR THE U.S. ENERGY RESEARCH AND DEVELOPMENT ADMINISTRATION UNDER CONTRACT ATIO7.2! 1 
This report was prepared as an account of work sponsored by the United States Government. Neither the United States nor the United States Energy Research and Development Administration, nor any of their contractors, subcontractors, or their employees, makes any warranty. express or implied, or assumes any legal liability or responsibility for the accuracy, completeness or usefulness of any information, apparatus, product or process disclosed, or represents that its use would not infringe privately owned rights.

Printed in the United Stutes of Americe

Available from

National Technical Information Service

U. S. Department of Commerce

5285 Port Royal Road

Springfield, Virginia 22161

Price: Printed Copy \$3.50; Microfiche \$2.25 
DP. 1403

Distribution Category: UC-70

\section{INTERIM SOLIDIFICATION OF SRP WASTE WITH SILICA, BENTONITE, OR PHOSPHORIC ACID \\ by \\ G. H. THOMPSON}

Approved by

W. H. Hale, Research Manager

Separations Chemistry Division

Publication Date: March 1976

E. I. DU PONT DE NEMOURS AND COMPANY SAVANNAH RIVER LABORATORY AIKEN, SOUTH CAROLINA 29801 


\section{ABSTRACT}

One option for interim waste management at the Savannah River Plant is in-tank solidification of the liquid waste solutions. This would reduce the mobility of these highly radioactive solutions until techniques for their long-term immobilization and storage are developed and implemented. Interim treatments must permit eventual retrieval of waste and subsequent incorporation into a high-integrity form. This study demonstrated the solidification of simulated alkaline waste solutions by reaction with silica, bentonite, and phosphoric acid. Results show that:

- Alkaline waste can be solidified by reaction with silica gel, silica flour, or sodium silicate solution. Solidified products containing waste salt can be retrieved by slurrying with water.

- Alkaline supernate (solution in equilibrium with alkaline sludge in SRP waste tanks) can be solidified by reaction with bentonite to form cancrinite powder. The solidified waste can be retrieved by slurrying with water.

- Alkaline supernate can be solidified by partial evaporation and reaction with phosphoric acid. Water is incorporated into hydrated complexes of trisodium phosphate. The product is soluble, but actual plant waste would not solidify completely because of decay heat.

- Reaction of simulated alkaline waste solutions with silica gel, silica flour, or bentonite increases the volume by a factor of 26 over that of evaporated waste; reaction with phosphoric acid results in a volume 1.5 times that of evaporated waste.

At present, the best method for in-tank solidification is by evaporation, a method that contributes no additional solids to the waste and does not compromise any waste management options. 
CONTENTS

Introduction 5
Solidification of Alkaline Waste with Silica 5
Solidification of Supernate with Bentonite 7
Solidification of Supernate with Phosphoric Acid 9
Conclusions 11
References 12




\section{INTERIM SOLIDIFICATION OF SRP WASTE WITH SILICA, BENTONITE, OR PHOSPHORIC ACID}

\section{INTRODUCTION}

Methods of solidification and storage of radioactive Savannah River Plant (SRP) process wastes are being studied at Savannah River Laboratory (SRL). The origins and characteristics of SRP wastes, the criteria for acceptable waste forms, and their potential for fixation of SRP wastes have been described. ${ }^{1}$ SRP waste comprises alkaline salt solution, salt cake, and an insoluble sludge layer containing large amounts of iron, aluminum, manganese, and other elements. Compositions of waste from various storage tanks vary considerably. Alternatives considered for long-term management of SRP waste include its incorporation into a highintegrity solid form, followed by storage in a retrievable surface storage facility on the SRP site. The waste could be shipped to a federal repository later, if desired. Solid waste forms being considered include concrete, ${ }^{2}$ glass, ${ }^{3}$ and aluminosilicate minerals. ${ }^{4}$

In addition to the long-term waste management program, there is a concurrent program to develop and improve methods for interim storage of liquid and crystallized waste. ${ }^{5}$ Because the long-term plan could include incorporation of all waste into a high-integrity form, interim treatments must permit retrieval of all waste for solidification. The interim treatments investigated in this work werc in-tank solidification (ITS) of alkaline wastes by reaction with silica, bentonite, or phosphoric acid. The bentonite and phosphoric acid processes were developed as ITS methods by Atlantic Richfield Hanford Company (ARHCO) for conversion of high-level tank-stored radioactive waste into solid form. ${ }^{6,7}$ This report describes work performed to demonstrate the feasibility of these three ITS methods for use with SRP wastes.

\section{SOLIDIFICATION OF ALKALINE WASTE WITH SILICA}

Reaction of waste supernate and sludge with $\mathrm{SiO}_{2}$ to form solid products was evaluated as a possible in-tank solidification method. Both silica gel and silica flour were tested. Silica gel is prepared by solidifying and gelling solutions of soluble silicates. ${ }^{B}$ The gel can be depolymerized by alkali to form polysilicate ions of different sizes and molecular weights. Ions of greater molecular weight are produced at higher mole ratios of $\mathrm{SiO}_{2}$ to $\mathrm{Na}_{2} \mathrm{O}$, and silicate ions are highly polymerized at 4 moles of $\mathrm{SiO}_{2}$ per mole 
of $\mathrm{Na}_{2} \mathrm{O}^{9}$ Concentration of solutions containing polysilicate ions increases polymerization and gives solid products. Silica flour is produced by grinding and sieving $\mathrm{SiO}_{2}$; the particle size of flour is $<400$ mesh.

In initial tests with only $\mathrm{NaOH}$, silica gel and silica flour were reacted with 1 to $8 \mathrm{M} \mathrm{NaOH}$ in sealed polypropylene tubes at 25 to $100^{\circ} \mathrm{C}$. Approximately $3 \mathrm{~g}$ of silica gel per $\mathrm{m} 1$ of $\mathrm{NaOH}$ or $4 \mathrm{~g}$ of silica flour per $\mathrm{ml}$ of $\mathrm{NaOH}$ was required for solidification. Excess liquid prevents solidification; excess silica gel or silica flour resulted in a powdery layer on the monolithic product. Solidification with silica flour required 2 weeks at $100^{\circ} \mathrm{C}$ and 4 months at $25^{\circ} \mathrm{C}$. Silica gel required 1 week at $100^{\circ} \mathrm{C}$ and 4 weeks at $25^{\circ} \mathrm{C}$. Silica flour and silica gel formed monolithic products with $\geqslant 4 \mathrm{M}$ $\mathrm{NaOH}$; less $\mathrm{NaOH}$ resulted in powdery forms (not monolithic). In tests to evaluate retrievability, all forms were easily slurried with water except the $4 \mathrm{M} \mathrm{NaOH}$ - silica gel form, which was insoluble.

These results indicate that $\mathrm{NaOH}$ and waste supernate must be in appropriate proportions to form sufficient polysilicate ions to promote solidification. At low $\mathrm{NaOH}$ concentration, not enough polysilicate ions are formed to give a monolithic product upon repolymerization; at high $\mathrm{NaOH}$ concentration, the polysilicate ions have lower molecular weights and are more soluble. More time is required to partially dissolve silica flour surfaces and form polysilicate ions because silica flour has a dense crystalline matrix of siliconoxygen-silicon tetrahedra; whereas, silica gel is an amorphous porous hydrogel. Silica gel reacted rapidly with $\geqslant 6 \mathrm{M} \mathrm{NaOH}$; the mixture solidified before all of the silica gel was incorporated.

In an additional test series, equal volumes of 1 to $8 \mathrm{M} \mathrm{NaOH}$ were reacted with 38 wt $\%$ sodium silicate solution in vented polypropylene tubes at 25 to $100^{\circ} \mathrm{C}$. Hard monolithic products resulted for all solutions that were reacted at $100^{\circ} \mathrm{C}$ for 2 weeks. At $60^{\circ} \mathrm{C}$, the reaction required up to 3 months; at $25^{\circ} \mathrm{C}$, samples containing $>5 \mathrm{M} \mathrm{NaOH}$ became highly viscous but did not solidify in 5 months. Samples prepared with 7 and $8 \mathrm{M} \mathrm{NaOH}$ and reacted at 60 and $100^{\circ} \mathrm{C}$ were hygroscopic and softened upon exposure to the atmosphere. A1l forms were soluble in water since the $\mathrm{SiO}_{2} / \mathrm{Na}_{2} \mathrm{O}$ ratio for 38 wt $\%$ sodium silicate solution is approximately 3.33 , and this ratio was decreased by the addition of $\mathrm{NaOH}$.

Aluminate ion (present in SRP waste supernate in varying amounts) reacts rapidly with silica gel to form insoluble aluminosilicates. Aluminate solutions $(0.4$ to $1.6 \mathrm{M})$ in 3 to $7 \mathrm{M}$ $\mathrm{NaOH}$ were reacted with silica gel at 25 to $100^{\circ} \mathrm{C}$. All products were insoluble, as expected, with reaction more rapid at higher temperatures and higher aluminate and $\mathrm{NaOH}$ concentrations. 
Simulated concentrated supernate $\left[10.8 \mathrm{M} \mathrm{Na}^{+}, 5.4 \mathrm{M} \mathrm{OH}^{-}, 0.75 \mathrm{M}\right.$ $\mathrm{Al}(\mathrm{OH})_{4}^{-}, 2.0 \mathrm{M} \mathrm{NO}_{3}{ }^{-}$, and $\left.2.65 \mathrm{M} \mathrm{NO}_{2}{ }^{-}\right]$was reacted with silica ge1 at $25^{\circ} \mathrm{C}$ for 1 month and at $100^{\circ} \mathrm{C}$ for 1 week; both forms produced were insoluble and monolithic. Evaporation of concentrated supernate to 75 and $50 \%$ of original volume causes salt crystallization upon cooling. These salt slurries, both with and without ironaluminum and iron-manganese sludges, reacted with silica gel to form monoliths. These monoliths can be slurried with water because soluble salts leach out, breaking up the monolithic structure into particles. Thus in the presence of aluminate ion, retrievability with this method of in-tank solidification would require only prior evaporation to a salt slurry. A major disadvantage of the silica gel method is, however, that it would increase the waste volume by a factor of six compared to simple evaporation of the waste. Evaporation of concentrated supernate to $40 \%$ of original volume results in a solidified salt cake.

\section{SOLIDIFICATION OF SUPERNATE WITH BENTONITE}

Mineralization with clay and $\mathrm{NaOH}$ was evaluated by ARHCO for in-tank solidification of alkaline wastes; reaction of neutralized simulated Purex waste solutions with bentonite (primarily montmorillonite, $\mathrm{Al}_{2} \mathrm{Si}_{4} \mathrm{O}_{11} \cdot \mathrm{H}_{2} \mathrm{O}$ ) at $100^{\circ} \mathrm{C}$ for 3 hours forms cancrinite, $6\left(\mathrm{NaAlSiO}_{4}\right) .^{6}$

In SRL tests, simulated concentrated supernate with ${ }^{137} \mathrm{Cs}$ tracer was reacted with bentonite and $\mathrm{NaOH}$ at $100^{\circ} \mathrm{C}$ for 3 hours to 7 days. Samples reacted $\geq 24$ hours were completely converted to cancrinite, provided $\mathrm{NaOH}$ was added to a $\mathrm{NaOH} /$ bentonite mole ratio of $2 / 1$. Waste solidification was considered complete. if no liquid could be removed by pressing at 100 psig. Complete solidification required $1.2 \mathrm{~g}$ of bentonite per $\mathrm{ml}$ of waste. The presence of sludge does not interfere with formation of cancrinite product. Cancrinite prepared from bentonite was not monolithic as was cancrinite prepared from kaolinite. ${ }^{4}$

Although low leachability is not a major goal for interim waste management, it was of interest to determine to what extent reaction of waste with bentonite would decrease the mobility of

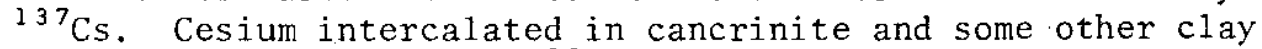
minerals is tightly bound. ${ }^{10}$ For this reason, cesium leach tests were made with the cancrinite product. Cancrinite for these tests was prepared from diluted supernate, but the ratios of $1.2 \mathrm{~g}$ of bentonite per ml of solution and $\sim 2$ moles of $\mathrm{NaOH}$ per mole of bentonite were maintained. 1-inch sections of moist compacted product were cut from the l-inch-diameter polypropylene reaction tubes for leach tests; the samples collapsed in the 
leachant (268 $\mathrm{ml}$ of distilled water), Leachant was changed daily for 4 days and weekly thereafter. ${ }^{1{ }^{37}} \mathrm{Cs}$ was determined by gamma spectroscopy. Results are shown in Table 1.

\section{TABLE 1}

Cesium Leached from Cancrinite Product

$\begin{array}{lll}\text { Bentonite/Salt } & \text { Fraction } \mathrm{Cs}^{+} \text {leached in } 90 \text { days } \\ \text { mole ratio } & 1.2 \mathrm{~g} \text { bentonite/m } & 1.4 \mathrm{~g} \text { bentonite } / \mathrm{ml} \\ 0.82 & 0.82 & 0.63 \\ 1.57 & 0.57 & 0.39 \\ 3.15 & 0.33 & 0.40 \\ 6.30 & 0.25 & 0.30\end{array}$

a. $17 \%$ bentonite unreacted.

The fraction of ${ }^{137} \mathrm{Cs}$ leached from cancrinite product decreased with dilution of waste salt to $10 \%$ of original concentration; further dilution had little effect. Leachabilities for cesium were between $2.1 \times 10^{-3}$ and $6.8 \times 10^{-3} \mathrm{~g} /\left(\mathrm{cm}^{2}\right.$-day $) .^{*} 60$ to $98 \%$ of the cesium leached was removed during the first week, indicating unreacted cesium and salt. Further reduction in leach rate would require washing and recycling unreacted waste from the cancrinite.

Cancrinite may be recovered by sluicing and centrifuging (it rapidly plugs filters), but the compacted product slurries rather slowly and recovery would be time consuming. The volume of the final product would be $\sim 6$ times greater than that of evaporated waste.

\section{SOLIDIFICATION OF SUPERNATE WITH PHOSPHORIC ACID}

The synthesis and stoichiometry of solid, hydrated sodium phosphate compounds were studied by Bell. ${ }^{11}$ He found that trisodium phosphates containing more than 8 moles of $\mathrm{H}_{2} \mathrm{O}$ per mole

* Cs leachability $=\frac{\text { (fraction of } \mathrm{Cs} \text { leached) (sample wt) }}{\text { (time) (area of monolithic form) }}$ 
of $\mathrm{Na}_{3} \mathrm{PO}_{4}$ are not simply hydrates, but are hydrated complexes that always contain either sodium hydroxide or the sodium salt of a monobasic acid. The salts of polybasic acids such as sodium sulfate or sodium carbonate do not form complexes. The general formula of the hydrated complex is $\mathrm{n}\left(\mathrm{Na}_{3} \mathrm{PO}_{4} \cdot \mathrm{XH}_{2} \mathrm{O}\right) \mathrm{NaY}$, where $n=4$ to $7, X=11$ or 12 , and $Y$ is a monobasic anion. Crystallization of these complexes from dilute solution by slow evaporation was less likely to produce a heterogeneous product because the excess liquor tends to minimize the effect of slight variations in starting composition. Table 2 lists the order in which some salts are incorporated into these complexes. If two or more salts capable of forming complexes are present, the highest melting complex forms first rather than a mixture of two or more complexes. $\mathrm{Na} / \mathrm{P}$ ratios and thermogravimetric analyses showed that two complexes formed: $5\left(\mathrm{Na}_{3} \mathrm{PO}_{4} \cdot 12 \mathrm{H}_{2} \mathrm{O}\right) \mathrm{NaOH}$ and $7\left(\mathrm{Na}_{3} \mathrm{PO}_{4} \cdot 12 \mathrm{H}_{2} \mathrm{O}\right) \mathrm{NaOH}$, referred to as $\mathrm{Na}-5$ and $\mathrm{Na}-7$, respectively.

\section{TABLE 2}

\begin{tabular}{|c|c|}
\hline $\begin{array}{l}\text { Complex-Forming } \\
\text { Salt }\end{array}$ & $\begin{array}{l}\text { Melting Temperature } \\
\text { of Complex, }{ }^{\circ} \mathrm{C}\end{array}$ \\
\hline $\mathrm{NaOH}$ & 74 \\
\hline $\mathrm{NaNO}_{2}$ & 72 \\
\hline $\mathrm{NaNO}_{3}$ & 60 \\
\hline
\end{tabular}

ARHCO evaluated the solidification of concentrated supernates by addition of phosphoric acid as part of the ITS program. ${ }^{7}$ The supernate $\left[10.28 \mathrm{M} \mathrm{Na}^{+}, 4.81 \mathrm{M} \mathrm{OH}^{-}, 2.30 \mathrm{M} \mathrm{A1}(\mathrm{OH})_{4}^{-}, 2.06 \mathrm{M} \mathrm{NO}_{3}{ }^{-}\right.$, and $1.11 \mathrm{M} \mathrm{NO}_{2}^{-}$] approached maximum solidification, nearly $100 \%$, at $\mathrm{Na} / \mathrm{P}=3.12 / 1$, which is closer to the theoretical value of 3.14 in $\mathrm{Na}-7$ than to 3.20 in $\mathrm{Na}-5$. ARHCO postulated that initial reaction of phosphoric acid with $\mathrm{NaOH}$ forms trisodium orthophosphate. As the heat of reaction raises the temperature to $290^{\circ} \mathrm{C}$, some local precipitation of $\mathrm{Al}(\mathrm{OH})_{3}$ occurs. As the slurry cools, complex hydrates form, taking on additional waters of hydration. The loss of water into the complex hydrates results in a solution supersaturated with $\mathrm{NaNO}_{3}, \mathrm{NaNO}_{2}$, and $\mathrm{VaAl}(\mathrm{OH})_{4}$, which also begin to crystallize. The remaining small amount of saturated $\mathrm{NaNO}_{3}-\mathrm{NaNO}_{2}$ solution is apparently occluded in the matrix by interfacial tension 
and van der wals forces. The ARHCO product was considered to be completely solidified if no solution could be removed by pressing at 28 psig. The product is water-soluble, loses water upon mechanical agitation, and has a melting range of 55 to $80^{\circ} \mathrm{C}$.

Simulated SRP supernate (Table 3) could not be solidified completely by addition of phosphoric acid: at least 9 volume \% water remained. Additional solutions were prepared by evaporating the original solution. A completely solid phosphate complex was obtained from a solution evaporated to $65 \%$ of original volume; ratios of available sodium* to phosphate for the solid product varied from 3.12 to 3.25 . The results of all tests are shown in Figure 1 .

\section{TABLE 3}

Composition of Simulated Concentrated SRP Supernates Molar, except $\mathrm{H}_{2} \mathrm{O}$ is wt $\%$

$\begin{array}{lllllll} & \mathrm{Na}^{+} & \mathrm{OH}^{-} & \mathrm{AZ}(\mathrm{OH})_{4}^{-} & \mathrm{NO}_{3}^{-} & \mathrm{NO}_{2}^{-} & \mathrm{H}_{2} \mathrm{O} \\ \text { Hanford } & 10.28 & 4.81 & 2.30 & 2.06 & 1.11 & 48 \\ \text { Savannah River } & 10.8 & 5.4 & 0.75 & 2.0 & 2.65 & 53.4\end{array}$

Aluminate affects waste solidification significantly. Simulated concentrated SRP supernate adjusted to 2 . OM aluminate can be solidified without preliminary evaporation. Hanford waste contains $2.3 \mathrm{M}$ aluminate and can be solidified without further evaporation.

Solidified waste corresponding to Point A in Figure 1 was tested for radiation and thermal stability. Irradiation to $10^{7}$, $10^{\theta}$, and $10^{9}$ rads increased volume by 0,14 , and $25 \%$, but no liquid was released. In the heating tests, melting began at $40^{\circ} \mathrm{C}$ and was not complete at $200^{\circ} \mathrm{C}$. Because SRP waste could reach $\sim 80^{\circ} \mathrm{C}$, even in cooled tanks, phosphate solidification is impractical for interim storage of SRP waste. The addition of phosphate would also compromise waste incorporation into glass, a high-integrity form being considered for eventual storage of waste; phosphate glasses devitrify at $\sim 400^{\circ} \mathrm{C}$ with a 1000 -fold increase in leach rate. ${ }^{12}$

* Available sodium = sum of hydroxide and aluminate concentrations. 


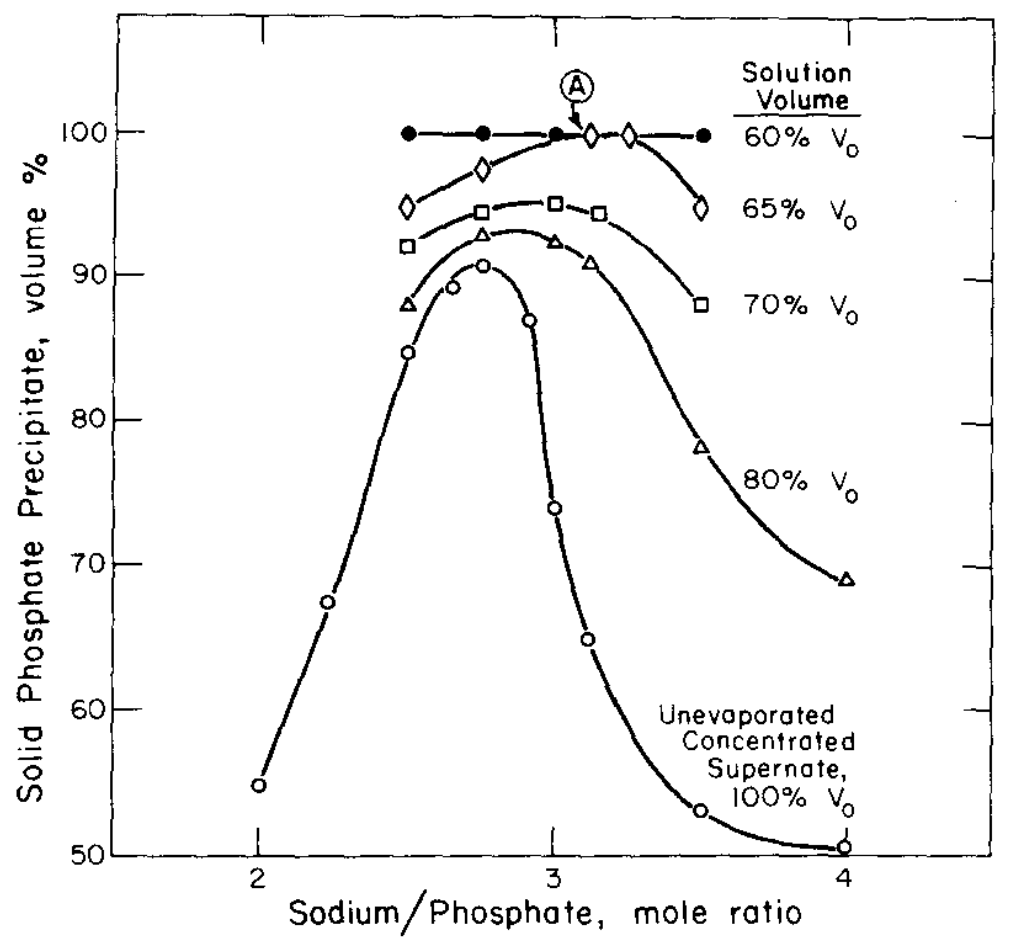

FIGURE 1. Effect of Waste Concentration on Solidification with Phosphoric Acid

In-tank solidification of alkaline waste by reaction with silica and bentonite is possible, but the final waste volume would be $v 6$ times greater than that of salt cake produced by evaporation. Phosphoric acid reacts with evaporated simulated supernate to give a solid product, but decay heat in waste would prevent complete solidification by this method. Also, addition of phosphate would be deleterious to subsequent waste incorporation in glass, a high-integrity waste form currently a candidate for long-term waste management at SRP.

At present, the best method for in-tank solidification is by evaporation, a method that contributes no additional solids to the waste and does not compromise any waste management options. 


\section{PEFERENCES}

1. R. M. Wallace, H. L. Hull, and R. F. Bradley. Solid Forms for Savonnah River Plant High-Level Waste. USAEC Report DP-1335, E. I. du Pont de Nemours \& Co., Savannah River Laboratory, Aiken, SC (1973).

2. J. A. Stone. Evaluation of Concrete as a Matrix for Solidification of Savannah River Plant Waste. USERDA Report DPE. I. du Pont de Nemours \& Co., Savannah River Laboratory, Aiken, SC (to be issued).

3. J. A. Kelley. Evaluation of Glass as a Matrix for Solidification of Savannah River Plant Waste, Nonradioactive and Tracer Studies. USERDA Report DP-1382, E. I. du Pont de Nemours \& Co., Savannah River Laboratory, Aiken, SC (1975).

4. G. H. Thompson. Evaluation of Mineralization Processes for SRP Wastes. USERDA Report DP-1389, E. I. du Pont de Nemours \& Co., Savannah River Laboratory, Aiken, SC (1975).

5. Integrated Radioactive Waste Management Plan. ERDA Report SRO-TWM-76-1, U.S. Energy Research and Development Administration, Savannah River Operations Office, Aiken, SC (to be issued).

6. G. S. Barney and L. E. Brownel1. Report of Invention: The Fixation of Radioactive Wastes in Cancrinite for Safe, LongTerm Storage. USAEC Report ARH-IR-195, Atlantic Richfield Hanford Company, Richland, WA (1973).

7. D. A. Puryear, J. S. Buckingham, and M. H. Campbel1. Phosphate Solidification of Caustic Process Solution Waste. USAEC Report ARH-SA-120, Atlantic Richfield Hanford Company, Richland, WA (1972).

8. J. G. Vail. Soluble Sizicates. Vol II, ACS Monograph Series, p 549, Reinhold, NY (1952).

9. R. K. Iler. The Colzoid Chemistry of Silica and Silicates. p 26, Corne11 University Press, Ithaca, NY (1955).

10. L. E. Brownell, C. H. Kindle, and T. L. Theis. Review of Literature Pertinent to the Aqueous Conversion of Radionuclides to Insoluble Silicates with selected References and Bibliography. USAEC Report ARH-2731, Atlantic Richfield Hanford Company, Richland, WA (1973).

11. R. N. Be11. "Hydrates of Trisodium Orthophosphate." Ind. Eng. Chem. 41, 2901 (1949).

12. J. E. Mendel and J. L. McElroy. Waste Solidification Program, Volume 10, Evaluation of Solidified Waste Products. USAEC Report BNWL-1666, Battelle Pacific Northwest Laboratories, Rich1and, WA (1972). 